\title{
Psychoneuroimmunology and Skin Diseases
}

\author{
Liborija Lugović Mihić $^{1,2}$, Domagoj Mihatović ${ }^{1}$ (D) , Mirna Šitum ${ }^{1,2}$ \\ ${ }^{1}$ Department of Dermatology and Venereology, Sestre milosrdnice University Hospital Centre, Zagreb, Croatia \\ ${ }^{2}$ School of Dental Medicine, University of Zagreb, Zagreb, Croatia
}

OPEN ACCESS

Correspondence: Domagoj Mihatović, mag.psych. domagoj.mihatovic@kbcsm.hr orcid.org/0000-0002-7321-8057

This article was submitted to RAD CASA - Medical Sciences as the review article

Conflict of Interest Statement: The authors declare that the research was conducted in the absence of any commercial or financial relationships that could be construed as a potential conflict of interest.

Received: 11 June 2019 Accepted: 24 June 2019 Published: 22 July 2019

Citation: Lugovic Mihic L, Mihatovic D and Situm M. Psychoneuroimmunology and skin diseases. RAD CASA - Medical Sciences. $537=46-47$ (2019): 25-36 DOI: $10.21857 /$ y6zolb8I7m

Copyright (C) 2019 Lugovic Mihic, Mihatovic and Situm. This is an open-access article distributed under the terms of the Creative Commons Attribution License (CC BY). The use, distribution or reproduction in other

forums is permitted, provided the

forums is permitted, provided the
original author(s) and the copyright original author(s) and the copyright
owners(s) are credited and that the owners $(s)$ are credited and that the
original publication in this journal is cited, in accordance whit accepted adacemic practice. No use, distribution or reproduction is permitted which does not comply with these terms.

\begin{abstract}
:
Psychoneuroimmunology has emerged as a broad interdisciplinary field examining the interaction between the psychological state, the nervous system, the endocrine system, and the immune system. Psychodermatology or psychocutaneous medicine is an intersection of psychiatry, psychology and dermatology. There is a growing awareness of the connection between psychosocial stress and somatic illnesses, including dermatological diseases. Psychosomatic factors are considered significant in more than a third of people suffering from skin diseases. Communication between the psyche and the skin is a complex interaction of psychological, immunologic and endocrine factors with the skin, involving a number of neuropeptides, interleukins and immune system mediators. The skin, being the largest organ of the body, is equipped with metabolic and endocrinological capacities that facilitate homeostatic control between internal and external environments. In addition to psychosocial stress, factors relevant for a psychoneuroimmunological approach to skin diseases include nutrition, gut and skin microbiota, sleep and circadian rhythm, physical activity, and orthomolecular medicine. Knowledge of psychoneuroimmunological mechanisms and factors relevant for a holistic approach is very important for a better and broader understanding of skin diseases, and for better therapeutic outcomes for patients.
\end{abstract}

KEYWORDS: psychoneuroimmunology, psychodermatology, skin diseases, stress, psoriasis, atopic dermatitis

\section{SAŽETAK:}

Psihoneuroimunologija se pojavila kao široko interdisciplinarno područje koje obuhvaća povezanost psihičkog stanja, živčanog sustava, endokrinološkog sustava i imunološkog sustava. Psihodermatologija ili psihokutana medicina područje je ispreplitanja psihijatrije, psihologije i dermatologije. Sve je veći broj spoznaja koja govore o vezi psihosocijalnog stresa i somatskih bolesti, uključujući dermatološke bolesti. Psihosomatski čimbenici smatraju se značajnima u više od trećine osoba oboljelih od kožnih bolesti. Komunikacija između psihe i kože uključuje složene interakcije između psiholoških, imunoloških i endokrinoloških čimbenika sa kožnim sustavom, u čemu sudjeluje niz stvorenih neuropeptida, interleukina i posrednika imunološkog sustava. Pritom je koža, kao najveći organ tijela, opremljena metaboličkim i endokrinološkim sposobnostima koje olakšavaju homeostatsku kontrolu između unutarnjih i vanjskih okruženja. Uz psihosocijalni stresa, čimbenici važni unutar psihoneuroimunološkog pristupa kožnim bolestima uključuju prehranu, mikrobiom crijeva i kože, spavanje i cirkadijalni ritam, fizičku aktivnost i ortomolekularnu medicinu. Poznavanje psihoneuroimunoloških mehanizama i čimbenika relevantnih za holistički pristup vrlo je važno zbog boljeg razumijevanje kožnih bolesti, a ujedno i za bolji terapijski ishod u bolesnika.

KLJUČNE RIJEČI: psihoneuroimunologija, psihodermatologija, kožne bolesti, stres, psorijaza, atopijski dermatitis 


\section{INTRODUCTION}

The central nervous system, the endocrine system and the immune system are very complex interrelated systems and are associated with various diseases, including skin diseases. Psychoneuroimmunology (PNI) has emerged as a broad interdisciplinary field examining the interaction between psychological states, the nervous system, the endocrine system and the immune system. Findings in this field explain the biochemical contact between brain, behaviour and the immune system. The hypothalamic-pituitary-adrenal (HPA) axis and its constituents play a major role in these processes. Psychoneuroimmunology is attempting to explain which psychological states and in what way affect the immune system, and thus the health of an individual. All sorts of stressors (e.g. academic failure, bereavement or jumping a parachute) can change the immune response of an individual by influencing the aforementioned three systems. The communication between psyche and skin itself involves a complex psycho-immuno-endocrine-cutaneous interrelation, involving a number of neuropeptides, interleukins, and immune system mediators ${ }^{1}$. The skin, the largest organ of the body, is equipped with metabolic and endocrine capacities that facilitate homeostatic control between internal and external factors. Many common dermatological diseases include some form of psychological influence on pathogenic processes during illness, which can significantly contribute to the course and outcome of the disease $e^{2,3}$. There is also a relationship between emotional stressors (acute or chronic), psychological/ psychiatric conditions and dermatoses such as psoriasis, atopic dermatitis, acne, alopecia, urticaria, HPV infections (e.g. viral warts), herpes simplex infection, vitiligo and prurigo ${ }^{4,5,6}$. The skin is inervated with a large network of sensory fibers and expresses many neurotransmitters and neuropeptide receptors that are also expressed by the central nervous system, including corticotropin-releasing hormone $(\mathrm{CRH})$, serotonin, prolactin and substance P7. Particularly important for communication between systems (including communication between skin and other systems) are cytokines that mediate communication between cells ${ }^{8}$. They also coordinate the development, maturation, and activity of cells of the immune system. The most common cytokins are interleukins ${ }^{2}$. Cytokines are the central elements of interaction between the immune system and behavior. Apart from local activity, they act globally on the whole organism. Proinflammatory cytokines affect tissue by stimulating the development of inflammatory reactions and attract other immune cells involved in healing from injuries. In addition to local activity, proinflammatory cytokines coordinate a complex set of various reactions in the body to fight infections and injuries, including those in the skin. Cytokines also induce nonspecific endocrine responses by activating the sympathetic nervous system leading to release of catecholamines from plasma and activation of the HPA axis ${ }^{9}$. This leads to release of adrenocorticotropic hormone (ACTH) and glucocorticoids, especially stressful levels of cortisol. Cortisol is one of the most important factors and indicators of stress.

\section{PSYCHOLOGICAL FACTORS, IMMUNE FUNCTION AND EFFECTS ON} HEALTH

In order for an organism to respond adequately to challenges and threats from the environment, there must exist a synchronised activation of psychological factors, the neuroendocrine system and the immune system. The generic psychoneuroimmunological model assumes that a stressful event triggers negative affective states. For example, people feel angry or sad in response to a stressful situation. Such emotions are accompanied by well known physiological changes such as changes in the autonomic nervous system and the neuroendocrine system. Negative stress-induced emotions affect the immune system indirectly through the neuroendocrine system, and neuroendocrine and immune changes directly affect health outcomes, including course and outcome of ilness. However, studies have shown that stress can also directly affect the neuroendocrine system and immune system, independently of emotions. Therefore, a modified psychoneuroimmunological model of stress was proposed which includes alternative relationships of stress with neuroendocrine and immune system. In the fields of psychoneuroimmunology and health psychology, there is growing interest in research that examines the mechanisms of the effects of psychological factors on immune functioning, health related behaviors, health outcomes and course of illness. Among these factors, the most often examined are various stressful experiences, coping with stressful events, behaviors related to personality characteristics and behaviors resulting from negative affectrive states, which are significant in the psychoneuroneuomological approach to disease ${ }^{10}$. Current research on the effects of stress on immune function suggest three potential mechanisms by which stress affects health and susceptibility to disease. These mechanisms include influence: (1) through the autonomic nervous system (sympathetic fibers descend from the brain directly into the lymphoid organs, releasing various substances that affect their function and thus ellicit an immune response); (2) through the endocrine system (psychological factors affect the HPA axis and sympathetic-adrenal-medullary (SAM) axis; various hormones are released that bind to leukocyte receptors and thus regulate their distribution and function); (3) through changes in health-related behaviors (during stress, worrying, turmoil, anxiety, depression, etc., people tend to engage in more health risk behaviors such as smoking, drinking alcohol, poor nutrition, inadequate sleeping habits, etc., which can exert an influence on the immune system and health outcomes) $)^{11,12}$

To properely assess these kind of influences on disease onset and exacerbation within the psychoneuroimmunological model, it is important to examine different types of stressful events, negative psychological experiences, mediating and moderating effects of coping, cognitive assessment or social support, measures of immune change and measures of health outcomes ${ }^{10}$. One should bare in mind that psychneurouromological findings are often obtained on the basis of a small number of available immune 
function indicators. Therefore, psychoneurimunological findings regarding immune system outcomes (not health outcomes) can provide information on the interdependence of behavior, the central nervous system and the immune system, but do not necessarily indicate changes in disease suceptability ${ }^{11}$.

\section{THE RELATIONSHIP BETWEEN PSYCHE AND SKIN}

Psychodermatology or psychocutaneous medicine as an intersection of psychiatry, psychology and dermatology most often classyfies disorders in these categories: primarily psychiatric disorders, secondary psychiatric disorders and psychosomatic disorders.

Primarily psychiatric disorders are functional states without an obvious somatic pathophysiological basis, undoubtedly caused by psychogenic factors. They can manifest themselves on the skin, but the underlying cause is actually a psychiatric disorder or a behavior disorder with an immediate effect on the skin. Primarily psychiatric disorders with skin manifestations and signs are encountered in clinical practice less frequently than psychosomatic disorders. Examples of primary psychiatric disorders are artefact dermatitis (a condition in which a person injures his or her own skin) and trichotillomania (a condition in which a person pulls their own hair). People with obsessive-compulsive disorder can also cause skin self-injury. Delulusion of parasitosis is a form of psychotic disorder in which a person has delusional ideas about the existence of parasites in their skin and inflicts damage to the skin with the intention of removing the parasites ${ }^{13}$.

Secondary psychiatric disorders most commonly occur in chronic dermatological disorders such as alopecia, cystic acne, hemangioma, psoriasis, vitiligo, or gigantic congenital nevi. Coping with chronic illness (especially if the illness affects physical appearance and is perceived as unsightly) can result in a secondary psychiatric disorder in the form of a depressive or anxiety disorder, or cause symptoms of anxiety, depression, loss of self-esteem, feelings of social isolation and shame. These are reactive psychological states resulting from a primarily dermatological disorder. People suffering from skin diseases are often considered to be caontagious, dirty, and can be avoided by other people and discriminated against. Also, it is possible that a person with a skin disease affecting visible areas of the skin cannot integrate the illness into his or her self-image, leading to possible psychological disturbances. The most common explanations for the high incidence of secondary psychiatric and psychological disorders are that (1) chronic skin disease causes many maladjustments throughout life and affects social functioning; (2) visibility of skin diseases exposes a person to negative reactions from the social environment and stigmatization, thereby decreasing their self-esteem; (3) chronic illness causes strong anxiety, emotional instability and loss of self-confidence, leading to reduction in working ability and quality of life ${ }^{13}$.

Psychosomatic disorders include dermatologic disorders whose onset end exacebation are influenced by stress. These disorders are associated with psychological and somatic causal factors that are jointly responsible for the onset, severity, exacerbation and duration of the disorder. Most commonly, there are signs of stress related exacerbation of symptoms regarding this category of psychodermatological disorders, but rarely is there talk of stress as a causal factor. Considering skin disease in the context of Engel's biopsychosocial model (by which health and disease are a result of interrelation between numerous biological, psychological and social factors) and the "diathesis-stress" model (by which the person inherits the predisposition for the development of a disease that is activated by a stressful event), stress can be referred to as an etiological factor. This is consistent with reports from patients in clinical practice where patients often report stressful events that preceded the onset of the disease ${ }^{13,14}$.

THE IMPORTANCE OF PSYCHONEUROIMMUNOLOGICAL MECHANISMS IN MANAGING SKIN DISEASES

Communication between psyche and skin is a complex interaction of psychological, immunologic and endocrine factors with the skin, involving a number of neuropeptides, interleukins and immune system mediators. The skin, being the largest organ of the body, is equipped with metabolic and endocrinological capacities that facilitate homeostatic control between internal and external environments ${ }^{4}$.

There is a growing awareness of the connection between psychosocial stress and somatic illnesses, including dermatological diseases. Psychosomatic factors are considered significant in more than a third of people suffering from skin diseases. Communication between psyche and skin involves psycho-neuro-endocrine-skin interactions involving brain, immune and skin activity. This communication encompasses different neuropeptides, interleukins, hormones and immune system mediators. There is clinical and experimental evidence that the brain can initiate, influence and/or stop biological skin events and that the skin (as an important part of the "diffuse brain") can modify the quality of sensations and perception ${ }^{15}$.

The main neuroendocrinological and neural pathways of pathophysiological effect of psychological, biological and social factors on immunity and development of disease are the HPA axis, SAM axis, and sympathetic and parasympathetic nervous system. These systems react to stressogenic stimuli and can cause pathological events and illness in conditions of acute and chronic stress. In the context of skin and skin diseases, the neuroendocrine substances originate from the nerve fibers that inervate it, or from the skin cells that produce/excrete humoral signaling molecules (neurotransmitters, neuropeptides and hormones) that enter the HPA axis and correspond with neurotransmitters, neuropeptides and hormones characteristic for that axis. Neuromediators produced in the skin include classical neurotransmitters (catecholamines and acetylcholine) produced and excreted from autonomic nerve fibers in skin and skin cells ${ }^{4}$.

Of all dermatoses, psoriasis is especially known as a disease 
significantly influenced by psychological factors 16 . Internal factors such as inheritance and external factors such as trauma, infections, skin flora, antigens, etc., are important in the pathogenesis of psoriasis. The disease sets on in a complex and dynamic interaction of genetic, environmental and immunological factors. It is assumed that immune regulation plays a central pathophysiological role in the development of psoriasis. Various physiological and psychological consequences have been reported in patients with psoriasis, such as itch, sleep disturbances (up to $80 \%$ of patients) and depression in patients with severe psoriasis (10-62\%). Several psychoneuroimmunological mechanisms that can stimulate the onset of psoriasis have been established: sensory nerves release neuropeptides (neurotensin, somatostatin, supstance $\mathrm{P}$ and nerve growth factor (NGF)) which activate keratinocyte proliferation in the skin 17,18 . Sensory nerves and C-fibers also release the calcitonin gene-related peptide (CGRP) which directly activates keratinocyte proliferation and stimulates endothelial cells in the skin. Furthermore, C-fibers release nitric oxide, while cholinergic fibers produce acetylcholine and vasoactive intestinal peptide (VIP) associated with vasodilation in the skin. Neuropeptides activate granulocytes and macrophages (via granulocyte-macrophage colony-stimulating factor, GM-CSF), attracting macrophages and monocytes which then excrete prostaglandin E2 (PGE2) and interleukin 10 (IL-10). In addition to increasing keratinocyte proliferation, these neurotransmitters stimulate $T$ lymphocytes and vasodilation. In addition, the release of neurotransmitters is responsible for the appearance of Koebner's phenomenon (which is typical for psoriasis and is caused by skin irritation $)^{5}$.

The incurability and chronicity of psoriasis, its unpredictability characterised by flare-ups, lesions on visible areas of the skin, prevalence among young people and occurance of comorbid conditions are all factors that affect a persons physical and psychological health, working ability and productivity, social functioning and quality of life in general. People suffering from psoriasis and psoriatic arthritis often experience feelings of helplessness, anger and frustration. Social stigmatization and feelings of rejection are not uncommon. Patients often report having experienced some form of stigmatization in the past, hiding their health status from their social environment, colegues at work, friends and even family and report being percieved as contagious. Psoriasis, as well as numerous other dermatological diseases, can have a significant effect on relationships between the patient and his or her environment, which can manifest in symptom exacerbation and worsening of the functionality of the individual as a whole ${ }^{19}$.

Due to psoriatic manifestations, patients often feel stigmatized and socially rejected which can lead to problems with self-image or self-esteem. Negative self-evaluation can lead to avoidance behaviours and social isolation, with negative implications for interpersonal relationships. Due to all of this, psoriasis can have a powerful impact on the quality of life and the psychological well-being of patients ${ }^{20}$. Research shows a high percentage of anxiety and depressive disorders in patients with psoriasis. The severity of disease correlates positively with depression and suicidal ideation ${ }^{13}$. Consequently, patients can experience high levels of stress that can exacerbate symptoms of psoriasis. Studies confirm this: daily stressors can act as triggers for symptom exacerbation, affecting treatment sucess and prolonging the time needed for recovery ${ }^{21,22}$. These findings can be interpreted from a psychoneuroimmunological perspective. Research suggests a disregulation in the HPA axis in a percentage of patients with psoriasis. A reduced glucocorticosteroid response to stressors, leading to insufficient immunosuppressive effects and maintainance of an increased level of proinflammatory cytokines, could account for a stress-induced exacerbation of symptoms. Stress also affects the peripheral nervous system modulating the nerve cell and neuropeptide network in the skin. Immunohistological analyses show an increased number of nerve endings that release neuropeptides in psoriatic lesions compared to lesion-free skin and skin of healthy people. One of these neuropeptides, substance $\mathrm{P}$, contributes to neurogenic inflammation by regulating proinflammatory cytokines ${ }^{20}$. In addition, psoriatic lesions contain higher concentrations of neuropeptides that are also found in higher concentrations in the brain during stressful events ${ }^{13}$. The psychoneuroimmunologic perspectives is also complemented by research showing beneficial effects of psychological interventions on the course of illness ${ }^{20}$.

Alongside psoriasis, atopic dermatitis and some other skin diseases are often associated with psychological and immune influences.

Atopic dermatitis is a common childhood disease, associated with immune disfunction, but also psychological factors. Although the exact etiology is not yet established, laboratory and clinical data point to a multifactorial pathogenesis that includes genetic and environmental factors. Psychological stress has been shown to be a trigger for symptom exacerbation in atopic dermatitis ${ }^{23,24,25}$. In patients with atopic dermatitis, immune responses by Th2 lymphocytic responses dominate, which is associated with activation of keratinocytes, Langerhans cells, dermal dendritic cells, endothelial cells, mast cells, B lymphocytes and eosinophils. According to findings in the last decade, stress stimulates the release of glucocorticoids that stimulate $\mathrm{Th} 2$ responses while inhibiting Th1 cellular responses ${ }^{26}$. In addition, stress can cause a hyperacute response with accompanying activation of T lymphocytes and mast cells, impaired regulation of the HPA axis, expression and release of neurogenic inflammation mediators, and dysfunction of normal epidermal barrier function ${ }^{27}$. In addition to HPA axis disregulation, stress-induced neuroimune effects reslting in skin inflammation also involve additional peripheral effects, glucocorticoid function disregulation and glucocorticoid receptor dysfunction ${ }^{2}$.

Several nervous system mechanisms possibly responsible for the occurrence of itch have also been noted. Cholinergic fibers 
release acetylcholine and produce VIP, leading to eosinophilic release of histamine and activation of peripheral itch receptors in the epidermis. The released histamine stimulates $\mathrm{H} 2$ and $\mathrm{H} 3$ brain receptors and activates central nervous system neurons that secrete opioid peptides which also stimulate peripheral itch receptors. Moreover, C-type sensory nerve fibers are activated; neuropeptides, neurokinin A, substance P and NGF are released, activating itch receptors. Also, interleukin 2 (IL-2) and prostaglandins can indirectly stimulate itch receptors ${ }^{4}$.

Acne, characterised by very recognisable lesions, is also viewed through interaction between skin and hormonal, immunological and psychological factors ${ }^{28,29}$. There is evidence that stress may cause and exacerbate acne. Vice versa, skin lesions can have a psychosocial impact on the person and alter nervous system activity. Both the peripheral and central nervous system have been shown to be associated with skin factors, with androgens being involved in the onset of the disease, formation of comedones and other manifestations $s^{30}$. Acne and seborrheic dermatitis may also occur due to neurogenic stimulation of sebaceous secretion mechanisms. Sensory nerves releases a variety of neuropeptides (neurotensin, somatostatin, substance P, NGF, melanocyte hormone and PPAR- $\bigotimes$ ) and proopiomelanocortin peptide which increase sebaceous gland secretion, thus contributing to the onset of the disease ${ }^{4}$.

Alopecia areata is an autoimmune disease mediated by $\mathrm{T}$ and B lymphocytes with immunological responses to hair follicle antigens (trichohyalin and specific keratin) ${ }^{5,31}$. The condition is associated with the human leukocyte antigen (HLA) or immunogenic and neuroendocrinological factors, with an important infuence of a number of factors, including psychological ones. During the immune reaction, autoantigens are recognised and reactions involving T lymphocytes and NK cells occur, leading to release of proinflammatory cytokines. Stress can have a negative effect on the disease as it prevents the production of ACTH,

$\triangle-\mathrm{MSH}$ and ACTH releasing hormone, leading to damage of the hair follicle and alopecia. There are other psychoneuroimmunological mechanisms at work: the release of calcitonin gene-related peptide, CGRP (type $\mathrm{C}$ and sympathetic fibers), which stimulates the immune response of Th1 lymphocyte and inhibits Th2 lymphocytes $^{31}$. Stimulation of B lymphocytes that produce IgG, along with the formation of an immune complex, and the activation of apoptosis in the hair follicle keratinocytes ultimately leads to alopecia. It is not uncommon for patients with alopecia areata to have adjustment and coping difficulties, anxiety or depression. Vitiligo is a multifactorial polygenic disorder with a complex pathogenesis, linked with both genetic and non-genetic factors - autoimmune factors, nervous system factors, melanocyte structure and function disorders, disorder in defense against free oxygen radicals, decreased melanocyte viability, growth factor and cytokine deficiency. The role of stress has also been recognized. Studies show that stress can trigger vitiligo, with patients often reporting some form of significant emotional stress preceding the onset of the disease. Stress-induced exacerbation of autoimmune and inflammatory diseases is mediated through neurotransmitters and hormones. Stress causes catecholamine secretion by stimulation of the HPA axis. More specifically, stress can trigger the production and release of corticoliberin by the hypothalamus, which then stimulates the pituitary gland and the release of adrenocorticotrophin. The adrenal glands, then, synthesize catecholamines, which are cytotoxic to melanocytes, whose destruction is a characteristic of vitiligo ${ }^{32}$.

The above mentioned are some of the most prominent dermatoses associated with psychoneuroimmunological factors, knowledge of which can be very important in clinical practice.

\section{STRESS AND SKIN DISEASES}

When reporting about being under stress, patients most often describe a state of difficult coping with the challenges from the environment and feeling tense and uncomfortable. Such experiences are omnipresent and common to all people, so various theories and definitions of stress have emerged over the years. Various internal and external influences can disrupt the dynamic equilibrium of an organism: mechanical (injuries); physical (heat, noise, light); chemical (toxic materials); biological (infections); lack of food, water or sleep; difficulties in exchanging information with the environment; difficulties in social interactions, danger and life-threatening situations. Such influences can lead to disordered homeostatic regulation of the organism. When the equilibrium cannot be restored by involuntary mobilization of biological resources or spontaneous behavioral changes, an alarm reaction is triggered within the body in the form of a stress reaction $^{33}$.

Stress can be viewed as a process that includes stressors (physically or psychologically challenging events) and strain (physiological or psychological response o fan organism to stressors), with an emphasis on the relationship between the person and environment. This process involves continuous interactions and adjustments called transactions, with the person and environment each affecting and being affected by the other. According to this view, stress is not just a stimulus or a response, but rather a process in which the person is an active agent who can influence the impact of a stressor through behavioral, cognitive and emotional strategies $^{34}$.

Stress can also be defined as the circumstance in which transactions lead a person to perceive a discrepancy between the physical or psychological demands of a situation and the resources of his or her biological, psychological, or social systems. Transactions in stress generally involve an assessment process called cognitive appraisal, by which people assess two factors: (1) whether a demand threatens their physical or psychological well-being and (2) the resources available for meeting the demand. These are called primary and secondary appraisal ${ }^{35,36}$. Therefore, in order for a person to experience stress, the person must first appraise an environmental challenge as threatening (primary appraisal). 
But even if the challenge is appraised as threatening, it does not mean that it will be stressful if a person feels that it has sufficient resources for coping (secondary appraisal). When demands are appraised as greater than our resources, a person may experience a great deal of stress. Appraising events as stressful depends on two types of factors - those that relate to the person and thonse that relate to the situation. Personal factors include intellectual, motivational and personality characteristics. For example, people with high self-asteem are likely to believe they have the resources to meet demands that require the strenghts they posess. If they percieve an event as stressful, they may interpret it as a challenge rather than a threat. On the other hand, people who score high on perfectionism have a tendency to appraise even minor issues as potentially very stressful. Also, the more important a threatened goal is, the more stress the person is likely to percieve. Regarding situatinal factors, events that involve very strong demands, that are immanent, ambiguous and are characterised by low controllability tend to be seen as more stressful ${ }^{34}$.

Iti $s$ important to have in mind the relationship between stress, the neuroendocrine system and disease. Physiological responses to stress and stress response control are mostly regulated by two components of the neuroendocrine system. These are the SAM and HPA axes. Both axes are associated with emotions, especially those related to stress. The SAM axis is sometimes referred to as the "fight-or-flight" or "strain" system, and the HPA axis as "distress" or "conservation-withdrawal" system. The first response to stress comes through the SAM axis, whose activity is strongly associated with acute emotions such as fear and anger. During stress the hypothalamus governs the transmission of sympathetic impulses to the bodily organs. It also stimulates the release of epinephrine, norepinephrine and other catecholamines into the bloodstream. During extreme stress and increased activation of the sympathetic system, the body is overwhelmed by epinephrine and norepinephrine, which increases the effects of sympathetic excitation even more. Through a feedback loop with the hypothalamus, epinephrine increases ACTH secretion and thereby maintains increased excitation of the HPA axis. In response to the perception of stress and threat, the hypothalamus releases corticotrophin $(\mathrm{CRH})$, whose central role in the stress process is the secretion of cortisol. CRH stimulates the frontal lobe of the pituitary gland, which releases adrenocorticotropic hormone (ACTH), beta-endorphin and prolactin. High levels of ACTH induce intense negative affective states. ACTH stimulates the adrenal gland cortex to increase glucocorticoid secretion, of which cortisol is the most important for stress. In order to restore system balance, glucocorticoids are released sometime later than epinephrine and norepinephrine. Cortisol provides the body with additional energy by increasing the concentration of amino acids in the blood, fatty acid secretion and glucose production from noncarbohydrates ${ }^{10,37}$.

Stress also causes changes in the amount of neuropeptides released along with neurotransmitters, and through which neurons communicate with each other. Classical neurotransmitters such as norepinephrine and epinephrine are co-localized with various neuropeptides, including enkephalins, which suggests that neuropeptides modulate tissue response to stress. There is evidence to indicate that individuals who exhibit high anxiety in potentially dangerous or uncomfortable situations have a higher serum level of substance $\mathrm{P}^{38}$. Cytokines also induce nonspecific endocrine responses by activating the sympathetic nervous system leading to release of catecholamines from plasma and activation of the HPA axis. This causes the release of ACTH and glucocorticoids, and especially stressful levels of cortisol ${ }^{10}$.

The interaction between the central nervous system and the immune system can be seen through four pathways through which these two systems communicate bidirectionally: (1) the immune system signals the central nervous system by means of chemical mediators, i.e. cytokines; (2) the central nervous system regulates the immune response via HPA axis, (3) immune system cells have adrenaline receptors and (4) immune system organs are inervated by both branches of the autonomic nervous system, i.e. sympathetic and parasympathetic. This bidirectional communication opens up many possibilities for considering the connection between human behavior and the immune system ${ }^{10}$. It is also important to mention the relationship between stress and immune function. The knowledge that components of the stress response affect immune function suggests that people's behavior can affect changes in immune function. It is known that emotions and cognitions can alter the activity of important limbic structures, including the hippocampus and amygdala. These changes can signal the hippocampus to modify hormonal secretion of the adrenal gland and sympathetic responses of the autonomic nervous system. Adrenal and sympathetic components of the stress response have a powerful effect on the immune system. Lymphoid tissues (thymus, spleen, lymph nodes) receive signals from sympathetic and parasympathetic neurons. Changes in autonomic activity affect these tissues and alter the development and activity of lymphocytes. In this way, the cells needed for defense are directly influenced with autonomic activity or changes in emotional states ${ }^{10}$. Lymphocytes have beta-adrenergic and cortisol receptors. The effects of catecholamines on lymphocyte receptors are complex, i.e. they can increase and/or decrease indicators of immune system functioning. Meta-analyses of the relationship between psychosocial stress and immune function measures show that the impact of stress is not exclusively immunosuppressive - it depends on the duration and type of stressful event and individual characteristics38. For example, stimulation of beta-receptors by epinephrine can reduce the ability of NK cells to enter the lymph nodes, i.e. sites where they usually contact and neutralize antigens. At the same time, adrenaline can cause a contraction of the spleen, releasing stored lymphocytes into the bloostream, thereby increasing their ability to migrate to sites of infection. Beta-adrenergic activation, which accompanies acute stress, can increase the number of NK 
cells in the bloodstream, but also reduce T-cells reproduction to appropriate stimuli ${ }^{10}$. During prolonged stress, phagocytosis is weakened, although the number of phagocytes in the peripheral blood increases. Chronic stress and depression are associated with increased neutrophils and elevated levels of proinflammatory cytokines in peripheral blood ${ }^{38}$. Therefore, instead of concluding that stress always inhibits immune system function, it is necessary to analyze specific situations where elevation or reduction of immune function occurs.

The immune system also has important interactions with the HPA axis. Stressful cortisol levels can inhibit immune function in a number of ways, leading to a decrease in frequency and strength of the immune system signals and reduction in the number and activity of cells involved in the immune response. Unlike the effects of sympathetic activity and circulating epinephrine, cortisol can cause very damaging effects on immune function. Therefore, it is important to be mindful of situations and emotional states that are associated with elevated levels of cortisol because they potentially degrade immune function and can have a role in development of disease. Also, immune cells such as $\mathrm{T}$ lymphocytes have receptors for a number of different neurotransmitters. In this way, cells of the immune system receive signals from the nervous system, which affects their functioning. One of the reasons why the link between neurotransmitters and the immune system is important is the fact that negative emotional states (e.g. anxiety and depression) affect the activity of neurotransmitters ${ }^{10}$. Thus, stressful situations that lead to negative emotional experiences can affect the functioning of the immune system and potentially also dermatological diseases.

\section{FACTORS RELEVANT FOR A PSIHONEUROIMMUNOLOGICAL AP- PROACH TO SKIN DISEASES}

In managing a patient with skin disease, one of the factors worth condiering is nutrition, as well as the effect of non-adequate nutrition on dermatological disease within the psychoneuroimmunological perspective ${ }^{39}$. For example, a patient may report of changes in nail or hair, which can be caused by lack of vitamins and minerals during disease or altered psychological state ${ }^{40}$. Sideropenic anemia, for example, can develop gradually during depression and related inadequate intake of vitamins or minerals, which can in turn be associated with the dermatological disease. In the clinical presentation, along with signs and symptoms typical for anemia, dermatological symptoms may also occur, indicating a need for assesment of nutritinal habits of the patient. In cases of dermatological diseases associated with etiologically psychological disorders, treatment should target psychological segments along with dermatological ones.

Other dietary influences associated with the patient's immune functioning and psychological state are also possible. For example, iron may be important in patients with skin ulceration and wound (which are often chronic) or in patients with certain diseases (such as lupus erythematosus) that are associated with anemia of chronic diseases ${ }^{40}$ It is important to examine potential anemia in these dermatological diseases, especially in delayed healing of skin wounds, so that iron deficiency can be treated which ultimately effects the dermatological disease. Vitamin D is also important for the skin and can be associated with patient's habits and conditions, which can in turn lead to deficiency 41. In addition, other factors related to vitamin $\mathrm{D}$, such as skin type (Fitzpatrick), gender, body mass index, physical activity, alcohol intake, and vitamin D receptor polymorphisms should be considered. Patients with dermatological diseases associated with photosensitivity who should avoid sun exposure and use photoprotection are also at risk vitamin D deficiency ${ }^{41,42}$.

The role of nutrition, microbiota, and orthomolecular medicine has been particularly studied regarding psoriasis. The role of diet in the treatment of psoriasis has been studied for many years. Recent observation of comorbid conditions associated with psoriasis has stimulated interest in nutrition as a method for improving comorbid states occuring with the primary skin disease. There is a bidirectional connection between psoriasis and obesity. Obesity is associated with an increased incidence of psoriasis, severity of disease and a reduced response to conventional treatment. Weight loss, as a result of intervention with a tailored hypocaloric diet, can be beneficial for overweight or obese patients with psoriasis by resulting in a significant improvement in disease severity. Many epidemiological studies indicate that a Mediterranean diet offers beneficial effects on health, especially on cardiovascular, metabolic, neoplastic and chronic inflammatory diseases ${ }^{43}$. Recent data shows that there is a statistically significant correlation between adherence to a Mediterranean diet and the PASI score which describes the severity of psoriasis. Specifically, there were more psoriatic patients among those who did not adhere to a Mediteranean diet. The study also showed consumption of extra virgin olive oil and fish to be independent predictors of the PASI score and levels of C-reactive protein (CRP), the main protein of the acute phase of inflammation ${ }^{44}$. A tailored Mediteranean diet with high intake of monounsaturated fatty acids and omega-3 polyunsaturated acids, vegetables, fruits and fibers, along with limited intake of saturated fats, simple carbohydrates and sugars, is sugested as a nutritionist approach in psoriasis patients ${ }^{43}$. The gut and the skin are connected in a complex way through what is called the "gut-skin axis" 45 . It appears that in patients with psoriasis the skin and intestinal microbiota is considerably modified, with a significantly reduced abundance of Akkermansia muciniphilia when compared to healthy controls46. A randomized double-blind placebo-controlled trial showed that patients treated with a daily oral dose of bacterial strain Lactobacillus parcasei NCC2461 exhibited decreased skin sensitivity, accelerated barrier function recovery and preserve skin more efficiently after treatment with agents such as sodium lactate and urea ${ }^{47}$. The development of microbiota-targeted therapy and its potential use for new diagnostic approaches to skin diseases is still in progress. 
Many patients with psoriasis use dietary supplements as a form of complementary medicine. The most commonly used are fish oil, selenium and zinc. Fish oil and omega-3 polyunsaturated fatty acids are the most common complementary supplements not only in psoriasis but also in patients with other dermatological diseases. An analysis of studies that examined fish oil supplementation has shown the effectiveness of fish oil in improving psoriasis symptoms if taken for a long time ${ }^{48}$. Al-

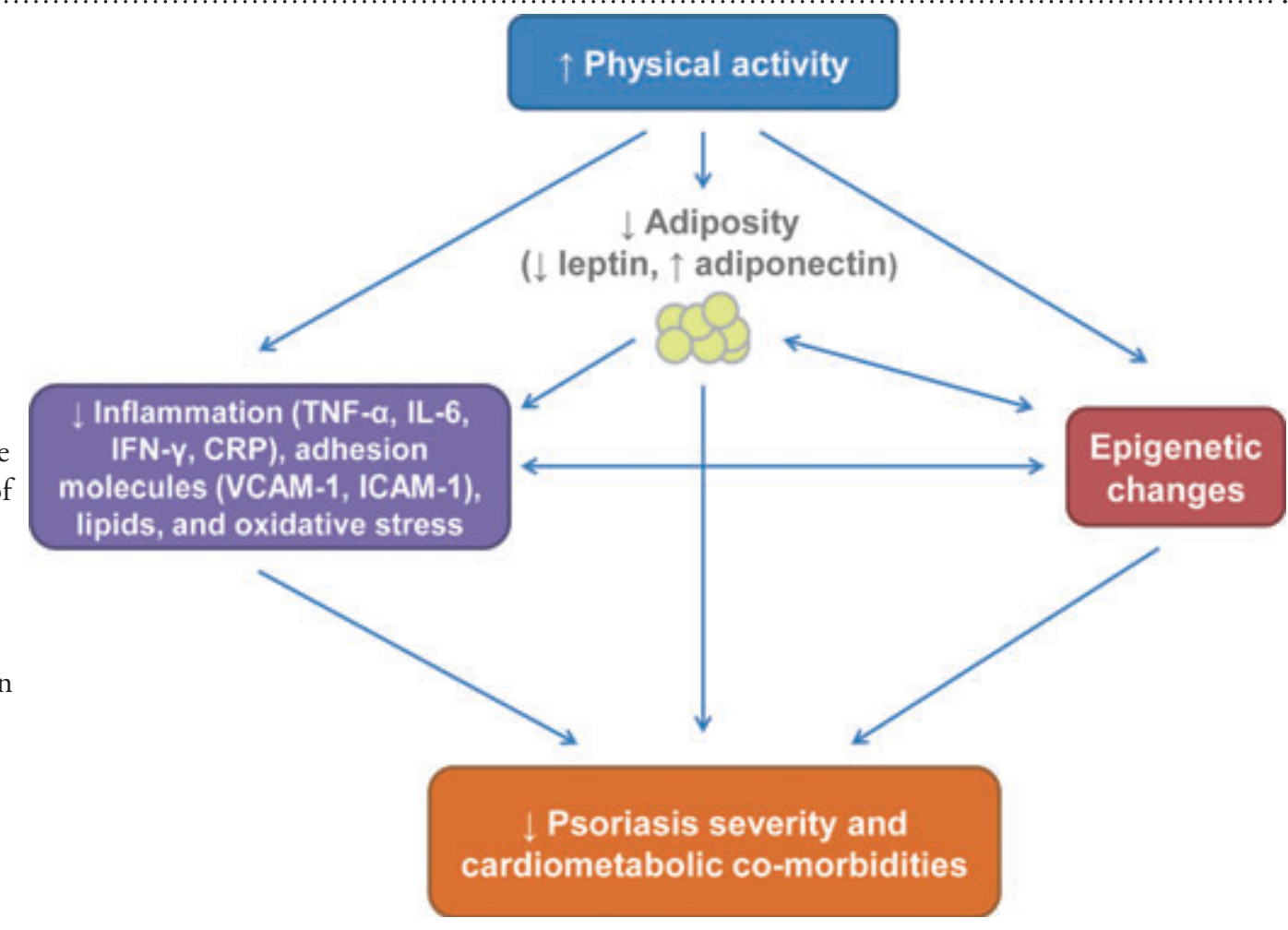
though zinc supplementation is common, the results on the the role of zinc in improving symptoms of psoriasis are inconclusive, with some studies showing positive effect, and some not ${ }^{43}$. Selenium is an essential element with antiproliferative and immunoregulatory properties. Reduced serum levels of selenium are associated with a more severe form of psoriasis. Studies have shown that selenium suplementation may be beneficial for those with altered serum levels of selenium, zinc, copper, total antioxidants and C-reactive protein ${ }^{49}$. A study using oral supplementation with a combination of micronutrients (folic acid, magnesium, iron, zinc, copper, manganese, selenium, chromium, iodine and vitamins $\mathrm{A}, \mathrm{D}, \mathrm{E}, \mathrm{K}, \mathrm{C}, \mathrm{B} 1, \mathrm{~B} 2, \mathrm{~B} 3, \mathrm{~B} 6$ and $\mathrm{B}_{12}$ ) during 3 months in combination with a low dose of methotrexate showed a significant improvement in the severity of psoriasis ${ }^{50}$.

Factors such as physical activity of the patient should also be considered, as well as the effect of this activity on the dermatological disease within the psychoneuroimmunological model. This was especially investigated in psoriasis and atopic dermatitis. It is known that psoriasis can increase the risk of developing other chronic diseases such as cardiovascular diseases, type 2 diabetes, obesity and metabolic syndrome. Physical activity is accepted as a vital component of prevention and treatment of cardiovascular diseases, type 2 diabetes, obesity and metabolic syndrome, which is why many people recommend it as an important element of psoriasis management ${ }^{51}$. Although not much research has studied the relationship between physical activity and psoriasis, the existing associates a greater prevalence of psoriasis and psoriasis severity with a lack of physical activity. It has also been found that lack of physical activity can be a risk factor for psoriasis, while psoriasis may also be a risk factor for reduced physical activity ${ }^{52}$. Future research should focus on specific interventions regarding physical activity on randomized samples. Potential mechanisms by which physical activity could reduce psoriasis severity and cardiometabolic co-morbidities has been proposed: physical activity may affect psoriasis pathophysiology via adipose tissue reductions and/or independent effects on

inflammatory molecules, adhesion molecules, lipids and oxidative stress. Some of these pathways may result from epigenetic changes such as DNA methylation, histone modifications, and RNA-associated gene silencing. Several of the pathways may overlap and flow bi-directionally, making an exact mapping of causative mechanisms challenging ${ }^{52}$.

Nutrition is also an important factor in patients with atopic dermatitis. Evidence suggests excessive body weight is associated with atopic dermaitis ${ }^{41}$. Patients with atopic dermatitis have multiple potential risk factors for reduced physical activity. Some features of the clinical presentation of atopic dermatitis contribute to this: patients with eczematous lesions on the hands and feet may have limited physical activity because of that; fatigue from sleep disturbances and depression may be indirectly associated with reduced physical activity; at the same time, heat, sweat and exercise are the most frequently reported circumstances leading to exacerbation of symptoms. Additionally, adult patients with atopic dermatitis, apart from reduced physical activity, also have significantly higher cardiovascular risk ${ }^{53,54,55}$.

Effects of sleep and circadian rhythm are also factors that should be taken into consideration in a psychoneuroimmunological approach to patients with dermatological diseases. Current evidence suggests that adequate sleep is very important for day-today functioning and maintenance of health, supporting optimal physiological and psychological functioning. Moreover, disturbed sleep is known to cause pathological processes in the body. For example, persistent sleep disorder is a risk factor for future development of diabetes, cardiovascular disease, hypertension and depression $^{56}$. Several studies have explored various domains of sleep in psoriasis patients. According to research literature, mood, obstructive sleep apnea, itching and pain are possible sources of sleep disorders ${ }^{56}$. Data also suggests that skin temperature, circadian rhythm and psychological factors such as depression, affect the onset of itch, which leads to disturbed sleep ${ }^{57}$. Increased prevalence of obstructive sleep apnea and restless leg syndrome 
in psoriasis patients has also been reported. Most studies have shown that sleep problems in psoriasis patients are related to itch, reduced mood and pain. It appears that itch is associated with increased sleep fragmentation, impaired sleep and decreased quality of sleep ${ }^{56}$. These findings are in line with research findings regarding other pruritic conditions. Reduced mood and pain are also associated with dysfunctional sleep as previously reported in healthy individuals and people with various other illnesses58. It is assumed that the interaction of reduced mood, pain and itch disrupts sleep, although the nature of this interaction requires a more detailed examination.

Significant experiences have also been observed in patients with atopic dermatitis. Intense itch (pruritus) during the night and the complex pathophysiology of atopic dermatitis can seriously affect sleep and become a major factor in the negative impact on the quality of life of a patient. Adults with atopic dermatitis often experience sleep disturbances, and data suggests that sleep quality worsens with the severity of atopic dermatitis. Itch and scratching significantly contributes to sleep disorders in children and adults with atopic dermatitis ${ }^{53,59}$.

The circadian rhythm itself is a biological clock that controls a number of physiological functions throughout the body, including various skin functions ${ }^{60}$. At the same time, skin cells express circadian "clock" genes, such as CLOCK (circadian locomotor output cycles coat), BMAL1 (brain and muscle aryl hydrocarbon receptor nuclear translocator-like protein 1), and Per1-3, which have autoregulatory feedback loops and maintain the rhythm of oscillating gene products. Studies have shown various skin physiology that is attuned to a circadian rhythm, such as transepidermal water loss (TEWL), skin permeability, $\mathrm{pH}$ of skin surface and skin temperature.

The 24-hour daily cycle (driven by an endogenous brain clock) largely controls the daily rhythm of the skin, which is also modulated by external factors (including temperature, humidity, nutrition and stress). Circadian rhythm affects skin blood flow and skin barrier function (e.g. transepidermal water loss) and plays an important role in atopic dermatitis. There are even suggestions for the implementation of chronotherapy to improve the outcomes of treatment for patients with atopic dermatitis. It is suggested that sleep disturbances in patients with atopic dermatitis are predominantly triggered by pruritus and scratching, although these are probably not the only etiological factors. Circadian rythms of cytokines, the immune system and skin physiology (e.g. transepidermal water loss and blood flow to the skin) can also play an important role ${ }^{60}$. There are data suggesting that atopic dermatitis is associated with attention deficit hyperactivity disorder, emotional and behavioral problems and delayed growth, which is thought to be associated with disturbed sleep. Sleep disorders can have many negative consequences, including impaired neurocognitive func- tion, more frequent behavioral problems and mood swings. The detection and treatment of these effects can be very useful in managing and treating the primary dermatological disease. Along with the effects on the aforementioned cytokines and immune cells, circadian rhythm may also affect atopic dermatitis in a number of other ways, primarily by way of cortisol. Cortisol levels are highest in the morning, and then they gradually decrease and reach the lowest point in the evening, shortly after the onset of sleep. It is assumed that this daily variation of cortisol levels contributes to increased itch at night in patients with atopic dermatitis and other skin diseases, since the anti-inflammatory effect of cortisol is minimal at that time. Discontinuation of circadian cortisol rhythm in patients with atopic dermatitis was observed in studies, although there are no studies directly investigating the relationship between cortisol levels and sleep disturbances.

In addition, recent studies indicate that melatonin may play a role in sleep disorders of patients with atopic dermatitis ${ }^{59}$. Melatonin is a hormone secreted by the pineal gland, and is essential for regulating sleep and circadian rhythm. It is excreted at a daily rate: secretion increases shortly after the onset of nighttime, with a peak in the middle of the night (between 2:00 and 4:00 AM), and gradualy declines during the second half of the night. Extrapineal melatonin has been found in multiple tissues such as skin, lymphocytes, mast cells, epithel of epithelial pathwyas, brain, retina, gastrointestinal tract and the reproductive tract. Various types of skin cells and lymphocytes produce melatonin and express melatonin receptors. Sleep is mostly in secondary focus in studies evaluating the treatment of atopic dermatitis, but several have evaluated treatment methods specifically aimed at improving sleep. There is currently no consensus on the treatment of sleep disorders in children with atopic dermatitis. First-generation antihistamines are most likely to be used due to their sedative effect, as they can cross the blood-brain barrier and affect the role of histamine in central nervous system excitation ${ }^{59}$.

Another important factor to consider is the microbiota and its effect on skin disease within the psychoneuroimmunological perspective $^{27,61}$. The skin microbiota, and other microbiotas, such as the gut microbiota, play a key role in pathogenesis and progression of atopic dermatitis. The skin microbiota mostly refers to skin organisms that promote the normal functions of the immune system and prevent pathogen colonization. On the other hand, the gut microbiota can modulate immune, metabolic and neuroendocrine functions. Various interventions aimed at microbiota characteristics are being developed to treat atopic dermatitis based on current research and underrstanding of the effects of microbiota on the onset of the disease ${ }^{27}$.

Still, it is not clear whether changes in the microbiota are a result of skin damage or if changes in the microbiota induce skin barrier disfunction and inflammation. However, in atopic dermatitis, 
communication between the microbiota and the immune system has been observed ${ }^{62}$. If, during early stages of life, it is altered, it can affect the maturation of innate and adaptive immunity. A new concept of posible influence on skin and gut microbiota modification (using hydrating agents containing unpathogenic biomass or probiotic supplements during early years of life) can be a preventive and therapeutic option in high-risk populations.

There is ample evidence supporting the view that the immune system is a key communication pathway between the gut and the brain, and that it plays an important role in stress-related psychopathology and represents a potential target for psychotropic intervention ${ }^{63}$. Gut microbiota is a complex ecosystem with a variety of organisms and a sophisticated genomic structure. It contains microbes that produce antimicrobial peptides, short chain fatty acids and vitamins, as well as most conventional neurotransmitters of the human brain. It has been found that the microbiological contents of the gut play a key role in the development of the immune system. Early interruption of reciprocal host-microbiota interaction may have lifelong consequences, not only in the function of the intestinal system but also in distal organs, including the brain ${ }^{27}$. The immune system and the nervous system are in constant communication to maintain homeostasis.

Research on germ-free animals, testing of infectious diseases models, research of prebiotics, probiotics, and antibiotics have increased the understanding of this interaction. Particularly important is stress during early years of life, which can have a lifelong effect on the microbial contents of the intestine and permanently change the immune system. This early life stress may also affect psychopathology at a later age, which has, for a long time, been acknowledged in psychiatry. It is necessary to decipher completely the molecular mechanisms that connect the gut microbiota, the immune system and the central nervous system to a web of communication that influences patterns of behavior and psychopathology, in order to use the knowledge in the human condition, in health and disease. There is evidence pointing to key communication points where microbiological gut intervention (with medication, diet or perhaps transplantation of fecal microbiota) can have a positive effect on mental health.

\section{PSYCHOLOGICAL INTERVENTIONS AS A FORM OF ADJUVANT THERAPY}

The psychoneuroimmunological perspectives is additionally complemented by research aimed at examining the beneficial effects of psychological interventions such as counseling, psychoeducation, psychotherapy and mindfulness on the course of the illness, as a form of adjuvant therapy directed at stress reduction64. With the basic tenets of psychoneuroimmunology and the effects of stress on the neuroendocrine system in mind, it is important to consider the potential benefit of psychological interventions aimed at better coping with (chronic) disease, ovecoming challenges the disease places on the individual, working through emotional difficulties one might face, coping with stress and providing support so as to mitigate the effects of psychosocial stress on skin disease.

The effects of psychological intervention is especially being investigated in patients with psoriasis. In one study, psoriasis patients treated with phototherapy were divided into two groups: one group served as a control, and in this group, patients received standard phototherapy; while the second group listened to mindfulness based stress reduction tape recordings during phototherapy. Subjects who listened to stress-reduction tapes recovered significantly faster than those that did not listen to the recordings $s^{65}$. The benefits of cognitive behavioral therapy have also been studied. In one study, the intervention group consisting of patients with psoriasis had been subjected to weekly sessions of cognitive behavioral therapy for a total duration of 6 weeks, with a focus on coping with symptoms of psoriasis along with standard medical treatment. After 6 weeks, patients in the therapy group showed significant reduction of symptoms of depression, anxiety and stress associated with psoriasis as well as the severity of the disease, compared to patients in the control group who received only standard treatment. Interestingly, these improvements remained significant after a six-month follow-up ${ }^{66}$.

Valuable data has also been presented on the benefits of mindfulness-based cognitive therapy (MBCT), a hybrid method of the two above-mentioned interventions, which uses awareness-focusing techniques to mitigate levels of physiological excitement and promotes effective mechamisms of coping with disease focused on acceptance. In a pilot study, the MBCT group showed significant improvements in the severity of disease and quality of life ${ }^{67}$. Research also shows a beneficial effect of psychological interventions for patients with atopic dermatitis. Interventions such as autogenic training, cognitive behavioral therapy, habit reversal training and stress reduction programs have been shown to be effective in reducing itch and scratching, and to also have a positive effect on anxiety, quality of life, and coping with stress ${ }^{64}$. Structured education programs for parents of children with atopic dermatitis have proven to be important for achieving the desirable health outcomes by providing knowledge and skills for better management of disease and coping with challenges that atopic dermatitis presents for the patient and his or her family ${ }^{68}$.

\section{ConClusion}

To conclude, knowledge of psychoneuroimmunology as a new interdisciplinary field and understanding of its mechanisms are very important for a better and broader understanding of skin diseases and for better therapeutic outcomes for patients.

\section{AUTHOR CONTRIBUTIONS:}

All authors listed have made a substantial, direct and intellectual contribution to the work, and approved it for publication. 


\section{LITERATURE:}

1. Evans, P, Hucklebridge, F, Clow, A. Mind, Immunity and Health: The Science of Psychoneuroimmunology. London: Free association books; 2000 .

2. Gabrilovac J. Neuroendokrina regulacija imunosnog odgovara u koži. U: Boranić M i sur, ur. Psihoneuroimunologija. Zagreb: Školska knjiga; 2008:103-15.

3. Honeyman JF. Psychoneuroimmunology and the skin. Acta Derm Venereol. 2016;96(217):38-46.

4. Lugović-Mihić L, Ljubešić L, Mihić J, Vuković-Cvetković V, Troskot N, Šitum M. Psychoneuroimmunologic aspects of skin diseases. Acta Clin Croat. 2013;52(3):337-45.

5. Lugović Mihić, L. Psihoneuroimunološki aspekti bolesti kože. U: Bralić I. Novi izazovi u prevenciji bolesti dječje dobi: koža ogledalo zdravlja i bolesti. Zbornik radova Simpozija; 2018.

6. Spiegel D. Mind matters in cancer survival. Psychooncology. 2012;21:588-93.

7. Maier SF, Watkins LR, Fleshner M. Psychoneuroimmunology. The interface between behavior, brain, and immunity. Am Psychol. 1994;49(12):1004-17.

8. Lugović L, Šitum M, Vurnek M, Buljan M. Influence of psychoneuroimmunologic factors on patients with malignant skin diseases. Acta Med Croatica. 2007;61(4):383-9.

9. Metzler-Wilson K, Toma K, Sammons DL, Mann S, Jurovcik AJ, Demidova O, i sur. Augmented supraorbital skin sympathetic nerve activity responses to symptom trigger events in rosacea patients. J Neurophysiol. 2015;114:1530-7.

10. Hudek-Knežević, J, Kardum, I. Stres i tjelesno zdravlje. Jastrebarsko: Naklada Slap; 2005.

11. Cohen S, Herbert TB. Health psychology: psychological factors and physical disease from the perspective of human psychoneuroimmunology. Annu Rev Psychol. 1996;47:113-42.

12 Glaser R, Kiecolt-Glaser JK. Stress-induced immune dysfunction: implications for health. Nat Rev Immunol. 2005;5(3):243-51.

13. Buljan D, Šitum M, Buljan M, Vurnek Živković M. Psihodermatologija. Jastrebarsko: Naklada Slap; 2008.

14. Buljan, D, ur. Konzultativno-suradna psihijatrija. Jastrebarsko: Naklada Slap; 2016.

15. Yan Q. Psychoneuroimmunology: Systems Biology Approaches to Mind-Body Medicine. Cham: Springer International Publishing Switzerland; 2016.

16. Dominguez PL, Han J, Li T, Ascherio A, Qureshi AA. Depression and the risk of psoriasis in US women. Eur Acad Dermatol Venereol. 2013;27:1163-7.

17. Moynihan J, Rieder E, Tausk F. Psychoneuroimmunology: the example of psoriasis. G Ital Dermatol Venereol. 2010;145(2):221-8. 18. Noormohammadpour P, Fakour Y, Nazemei MJ, Ehsani A, Gholamali F, Morteza A, i sur. Evaluation of some psychological factors in psoriatic patients. Iran J Psychiatry. 2015;10:37-42.

19. Hadžigrahić N, Malkić Salihbegović E, Kurtalić N, Kurtalić S, Omerkić E. Kvaliteta života oboljelih od psorijaze u odnosu na težinu kliničke slike i prisutnost komorbiditeta. Acta Med Croat,
2017;71(4): 257-61.

20. Kwon CW, Fried RG, Nousari Y, Ritchlin C, Tausk F. Psoriasis: Psychosomatic, somatopsychic, or both? Clin Dermatol. 2018;36(6):698-703.

21. Verhoeven EW, Kraaimaat FW, de Jong EM, Schalkwijk J, van de Kerkhof PC, Evers AW. Individual differences in the effect of daily stressors on psoriasis: a prospective study. Br J Dermatol. 2009;161(2):295-9.

22. Verhoeven EW, Kraaimaat FW, Jong EM, Schalkwijk J, van de Kerkhof PC, Evers AW. Effect of daily stressors on psoriasis: a prospective study. J Invest Dermatol. 2009;129(8):2075-7.

23. Suárez AL, Feramisco JD, Koo J, Steinhoff M. Psychoneuroimmunology of psychological stress and atopic dermatitis: pathophysiologic and therapeutic updates. Acta Derm Venereol. 2012;92(1):7-15.

24. Buddenkotte J, Steinhoff M. Pathophysiology and therapy of pruritus in allergic and atopic diseases. Allergy. 2010;65(7):805-21. 25. Chida Y, Steptoe A, Hirakawa N, Sudo N, Kubo C. The effects of psychological intervention on atopic dermatitis. A systematic review and meta-analysis. Int Arch Allergy Immunol. 2007;144(1):1-9. 26. Lugović L, Lipozenčić J, Jakic-Razumovic J. Prominent involvement of activated Th1-subset of T-cells and increased expression of receptor for IFN-gamma on keratinocytes in atopic dermatitis acute skin lesions. Int Arch Allergy Immunol. 2005;137(2):125-33.

27. Kim JE, Kim HS. Microbiome of the skin and gut in atopic dermatitis (AD): understanding the pathophysiology and finding novel management strategies. J Clin Med. 2019;8(4):444.

28. Chiriac A, Brzezinski P, Pinteala T, Chiriac AE, Foia L. Common psychocutaneous disorders in children. Neuropsychiatr Dis Treat. 2015;11:333-7.

29. Durai PC, Nair DG. Acne vulgaris and quality of life among young adults in South India. Indian J Dermatol. 2015;60:33-40. 30. Nguyen CM, Koo J, Cordoro KM. Psychodermatologic effects of atopic dermatitis and acne: a review on self-esteem and identity. Pediatr Dermatol. 2016;33(2):129-35.

31. Gregoriou S, Papafragkaki D, Kontochristopoulos G, Rallis E, Kalogeromitros D, Rigopoulos D. Cytokines and other mediators in alopecia areata. Mediators Inflamm. 2010;2010:928030. doi: $10.1155 / 2010 / 928030$.

32. Šitum, M, Stanimirović, A. Vitiligo - perspektive i smjernice. Zagreb: Hrvatska akademija znanosti i umjetnosti i Hrvatsko dermatovenerološko društvo Hrvatskog liječničkog zbora; 2014.

33. Schedlowski, M, Tewes, U. Psychoneuroimmunology: An Interdisciplinary Introduction. New York: Springer; 1999.

34. Sarafino, EP, Smith, TW. Health psychology: Biopsychosocial interactions. New Jersey: Wiley; 2014.

35. Lazarus, RS. Stress and emotion: A new synthesis. New York: Springer; 1999.

36. Lazarus, RS, Folkman, S. Stress, appraisal, and coping. New York: Springer; 1984.

37. Meštrović-Štefekov J, Pap N, Lugović-Mihić L, Novak-Bilić G, Kuna M. Psychological stress in atopic dermatitis. Acta Dermatovenerol Croat. 2018; 26(4):297-303. 
38. Daruna, JH. Introduction to Psychoneuroimmunology. London: Academic Press; 2012.

39. Ricketts JR, Rothe MJ, Grant-Kels JM. Nutrition and psoriasis. Clin Dermatol. 2010;28(6):615-26.

40. Wright JA, Richards T, Srai SK. The role of iron in the skin and cutaneous wound healing. Front Pharmacol. 2014;5:156.

41. Kechichian E, Ezzedine K. Vitamin D and the skin: an update for dermatologists. Am J Clin Dermatol. 2018;19(2):223-35.

42. Silverberg JI, Song J, Pinto D, Yu SH, Gilbert AL, Dunlop DD, Chang RW. Atopic dermatitis is associated with less physical activity in us adults. J Invest Dermatol. 2016;136(8):1714-6.

43. Zuccotti E, Oliveri M, Girometta C, Ratto D, Di Iorio C, Occhinegro A, Rossi P. Nutritional strategies for psoriasis: current scientific evidence in clinical trials. Eur Rev Med Pharmacol Sci. 2018;22(23):8537-51.

44. Barrea L, Balato N, Di Somma C, Macchia PE, Napolitano M, Savanelli MC, et al. Nutrition and psoriasis: is there any association between the severity of the disease and adherence to the Mediterranean diet? J Transl Med. 2015;13:18.

45. O’Neill CA, Monteleone G, McLaughlin JT, Paus R. The gutskin axis in health and disease: a paradigm with therapeutic implications. BioEssays. 2016;38:1167-76.

46. Tan L, Zhao S, Zhu W, Wu L, Li J, Sheng M, Lei L, Chen X, Peng C. The Akkermansia muciniphila is a gut microbiota signature in psoriasis. Exp Dermatol. 2018;27:144-9.

47. Gueniche A, Philippe D, Bastien P, Reuteler G, Blum S, Castiel-Higounenc I, et al. Randomised double-blind placebo-controlled study of the effect of Lactobacillus paracasei NCC 2461 on skin reactivity. Benef Microbes. 2013;5:137-45.

48. Millsop JW, Bhatia BK, Debbaneh M, Koo J, Liao W. Diet and psoriasis, part III: role of nutritionalsupplements. J Am Acad Dermatol. 2014;71: 561-9.

49. Wacemicz M, Socha K, Soroczynska J, Niczyporuk M, Aleksiejczuk P, Ostrowska J, et al. Concentration of selenium, zinc, copper, $\mathrm{Cu} / \mathrm{Zn}$ ratio, total antioxidant status and c-reactive protein in the serum of patients with psoriasis treated by narrow-band ultraviolet B phototherapy: a case-control study. J Trace Elem Med Biol 2017;44:109-14.

50. Yousefzadeh H, Jabbari Azad F, Banihashemi M, Rastin M, Mahmoudi M. Evaluation of psoriasis severity and inflammatory responses under concomitant treatment with methotrexate plus micronutrients for psoriasis vulgaris: a randomized blind trial. Acta Dermatovenerol Alp Pannonica Adriat. 2017;26:3-9.

51. Treloar V. Integrative dermatology for psoriasis: facts and controversies. Clinics Dermatol. 2010; 28: 93-9.

52. Wilson PB, Bohjanen KA, Ingraham SJ, Leon AS. Psoriasis and physical activity: a review. J Eur Acad Dermatol Venereol. 2012;26(11):1345-53.
53. Jeon C, Yan D, Nakamura M, Sekhon S, Bhutani T, Berger T, Liao W. Frequency and management of sleep disturbance in adults with atopic dermatitis: A Systematic Review. Dermatol Ther (Heidelb). 2017;7(3):349-64.

54. Asahina M, Poudel A, Hirano S. Sweating on the palm and sole: physiological and clinical relevance. Clin Auton Res. 2015;25:153-9. 55. Shibasaki M, Crandall CG. Mechanisms and controllers of eccrine sweating in humans. Front Biosci (Schol Ed). 2010;2:685-96. 56. Henry AL, Kyle SD, Bhandari S, Chisholm A, Griffiths CE, Bundy C. Measurement, Classification and Evaluation of Sleep Disturbance in Psoriasis: A Systematic Review. PLoS One. 2016 Jun 21;11(6):e0157843.

57. Thorburn PT, Riha RL. Skin disorders and sleep in adults: where is the evidence? Sleep Med Rev. 2010; 14(6):351-8.

58. Gowda S, Goldblum OM, McCall WV, Feldman SR. Factors affecting sleep quality in patients with psoriasis. JAAD. 2010; 63(1):114-23.

59. Chang YS, Chiang BL Mechanism of sleep disturbance in children with atopic dermatitis and the role of the circadian rhythm and melatonin. Int J Mol Sci. 2016; 17(4):462.

60. Vaughn AR, Clark AK, Sivamani RK, Shi VY. Circadian rhythm in atopic dermatitis-Pathophysiology and implications for chronotherapy. Pediatr Dermatol. 2018;35(1):152-7.

61. Dinan TG, Cryan JF. Microbes, immunity, and behavior: psychoneuroimmunology meets the microbiome. Neuropsychopharmacology. 2017;42(1):178-92.

62. Dou J, Zeng J, Wu K, Tan W, Gao L, Lu J. Microbiosis in pathogenesis and intervention of atopic dermatitis. Int Immunopharmacol. 2019;69:263-9.

63. Vedhera K, Irwin M, ur. Human psychoneuroimmunology. Oxford: Oxford Press; 2005.

64. de Zoysa P. Psychological interventions in dermatology. Indian J Dermatol. 2013;58(1):56-60.

65. Kabat-Zinn J, Wheeler E, Light T, et al. Influence of a mindfulness meditation-based stress reduction intervention on rates of skin clearing in patients with moderate to severe psoriasis undergoing phototherapy (UVB) and photochemotherapy (PUVA). Psychosom Med. 1998;60:625-32.

66. Fortune DG, Richards HL, Kirby B, et al. A cognitive-behavioural symptom management programme as an adjunct in psoriasis therapy. Br J Dermatol. 2002;146:458-65.

67. Fordham B, Griffiths CE, Bundy C. A pilot study examining mindfulness-based cognitive therapy in psoriasis. Psychol Health Med. 2015;20:121-127.

68. Ersser SJ, Cowdell F, Latter S, Gardiner E, Flohr C, Thompson AR, et al. Psychological and educational interventions for atopic eczema in children. Cochrane Database Syst Rev. 2014 Jan 7;(1):CD004054. 